\section{Subantarctic Campbell Island}

By Alfred M. Bailey and J. H. Sorensen. (Proceedings of the Denver Museum of Natural History, No. 10). Pp. iii + 305 (232 photographs). (Denvor : Denver Museum of Natural History, 1962.) 7 dollars.

7 HE Denver Museum of Natural History arranged an expedition during January and February 1958 to Campbell Island, south of New Zealand. As the authors admit, the result of two months field work cannot be the basis for a book, but with the idea of producing an interesting account of the natural history for people in tho United States, the gaps have been filled from existing literature.

The history of tho island is given from its discovery in 1810, and includes reforoncos to scientific expeditions from the Erebus and Terror in 1840 to the Galathea in 1952. The geology and flora are noted, but more than three-quarters of the book is dovoted to the fauna. Sightings of Right whales are given, and an aceount of the seals. The lattor is slightly marred by the incorrect and confusing use of the term 'sea bear' for a female sea-tion, but this fault is redeemed by the inclusion of proviously unpublished notos on seals that are not well documontod.

As is almost inevitablo, the book is primarily for the ornithologist. The history of the ornithological work is given, and a list of recorded birds. All sixty-one of these are described, although less than half breed on the island, and there are numerous weights and measurements. Particular attention is paid to the Wandering and Royal albatrosses, with notes on the hatching and growth of the chicks.

The book fulfils its purpose in giving a comprehonsive account, is woll presented, and the photographs in particular are excellent.

JUDITH E. KING

\section{The Theory of Ordinary Differential Equations}

By Dr. J. C. Burkill. (University Mathematical Texts.) Pp. ix + 114. (Edinburgh and London: Oliver and Boyd, Ltd.; Now York: Interscience Publishers, Inc., 1962.) 8s. $6 d$.

$\mathrm{D}$ R. BURKILL'S clear and concise text is one of the best in an admirablo series. It is not concerned with the elementary techniques of explicit integration, but gives in brief compass a remarkable amount of in. formation on what a differential equation can reveal about a function which satisfies it. Existence theorems, the Sturm-Liouville oscillation theory, solution in series leading to Legendre and Bessel functions, solution by contour integrals and by asymptotic serics, are oll expounded with rigorous simplicity and clarity. The new edition contains sections on the Laplace transform and on the equation $P \mathrm{~d} x+Q \mathrm{~d} y+R \mathrm{~d} z=0$.

\section{T. A. A. Broldbent}

\section{Fluorescent Protein Tracing}

Edited by Dr. R. C. Nairn. Pp. xv +280 . (Edinburgh and London: E. and S. Livingstone, Ltd., 1962.) 42s. net.

Thinitior HE use of fluorochromes as labels for antibodies was introduced by Coons some twenty years ago. This major advance resulted in the development of the technique of immunofluorescence which combines the sensitivity and specificity of immunological reactions with the precise visualization afforded by microscopy. This tochnique makes it possible to detcet and localize minute amounts of antigens and antibodies in biological materials. Immunofluorescence has been applied with much success to many diverse research problems and is being used increasingly in routine clinical diagnosis.

There has boon a need for a convenient source of information on the practical details and applications of this important technique. The survey of the principlos of the technique, the mothods of preparing fluorescent conjugates, the use of these conjugates in medical and biological research and the extensive bibliography given by Nairn and his colleagues in their monograph satisfies this need. The practical aspects of the method are emphasized and are dealt with authoritatively and com. prehensively. The chapter on fluorescence microscopy and photomicrography is excollent. The principles of the technique are dealt with briofly but adequately and the eritical review of the applications of the method is satisfactory. The most successful parts of the book are, how ever, those devoted to practical information and to the applications in which the authors have had personal exporience. The book is attractively produced and thero are some excellent illustrations.

Immunofluorescence will, undoubtedly, be used in the future by many investigators of varied scientific disciplines. This book will be invaluable to them.

\section{J. Crumpton}

\section{Geodesy}

By G. Bomford. Pp. xvi+561. (Oxford: The Clarendon Press: Oxford University Press, 1962, second edition.) $90 s$.

$7 \mathrm{HE}$ study of geodesy, the detormination of the Earth's shape is, of course, a venerable one dating back to tho determination of tho radius of the Earth by Eratosthenes, who measured the difference in the direction of the vortical at the two ends of a north-south are.

Tho present book contains an exhaustive account of the modern methods of determining the shape of the Earth by the methods of triangulation and traverse levelling and by astronomical measurements. The subject soon becomes involved in the general problems of geophysics, for verticals are doflected by the unequal distribution of matter at the Earth's surfaco. We find, therefore. in Brigadier Bomford's book very useful accounts of the theory of the Earth's gravitational field, isostasy and the subtle distinctions betwoen the geoid and co-gooid.

Thore are very useful discussions of the mathematical methods used in geophysies, such as apherical harmonics. The new editicn contains discussions, of courso, on the use of Earth satellite observations. This work is primarily for the specialist rather than for a person generally interested in the subject.

S. K. RunCORN

\section{Animal Health and Production}

Proceedings of the Thirteenth Symposium of the Colston Rosearch Society, held in the University of Bristol, April 10th-13th, 1961. Edited by C. S. Grunsell and A. I. Wright. Pp. xi+224. (London: Butterworth and Co. (Publishers), Ltd., 1962.) 42s.

7 HE title on the book covor is not very helpful. The thirtoon discussions at the thirteenth conference hold by the Socinty coverod a range of unrelated subjects, all of importance. Some of the subjects have received groat attontion in recent years, notably magnesium metabolism in cattle, by Th. do Groot (The Netherlands), and two on bovine ketosis, one by S. J. Bach and tho other by K. Peeters, W. Oyaert and J. H. Bouckaert (The Netherlands). Immunity was represented by papers on bacteriostatic properties of $C l$. welchii, Type $A$, by J. J. Bullen and A. Dobson; by the value of living viral vaccines, by S. E. Piercy; by immunity to helminths, by E. J. L. Soulsby; by antigens and antibodios in the new-born, by A. E. Pierce; and by non-specific rosisteneo to infectious disoases, by A. W. Gledhill. Three papers concemed poultry: sex hormono balance, by J. G. Campbell; Marek's disease and lymphoid leukosis, by P. M. Biggs; and avian visceral lymphomatosis and related neoplasms, by R. R. Burmcister and T. N. Fredrickson.

The discussions are dealt with by brief accounts of what each speaker said, but with nearly as much space for names as for text and are not very informative. 